\title{
Livelihood Patterns and Socio-economic Conditions of the Fishermen of Kharingcha Baor at Chaugachha Upazilla in Jashore District, Bangladesh
}

\author{
Md. Raihan Uddin ${ }^{1}$, M. Aminur Rahman ${ }^{1 *}$, Moumita Choudhury ${ }^{2}$, \\ Md. Almamun Farid ${ }^{1}$, Anusree Biswas ${ }^{1}$ and M. Anisur Rahman ${ }^{1 *}$ \\ ${ }^{1}$ Department of Fisheries and Marine Bioscience, Faculty of Biological Science and Technology, \\ Jashore University of Science and Technology, Jashore-7408, Bangladesh. \\ ${ }^{2}$ Department of Environmental Science and Technology, Faculty of Applied Science and Technology, \\ Jashore University of Science and Technology, Jashore-7408, Bangladesh.
}

Authors' contributions

This work was carried out in collaboration among all authors. All authors read and approved the final manuscript.

Article Information

DOI: 10.9734/ARRB/2021/v36i530376

Editor(s):

(1) Dr. Manikant Tripathi, Dr. Ram Manohar Lohia Avadh University, India.

Reviewers:

(1) Usha Chirala, Andhra University, India.

(2) Abd. Rahim, Universitas Negeri Makassar, Indonesia.

Complete Peer review History: http://www.sdiarticle4.com/review-history/68743

Original Research Article

Received 25 March 2021

Accepted 29 May 2021

Published 04 June 2021

\section{ABSTRACT}

A field study was carried out to investigate the livelihood patterns and socio-economic conditions of the small-scale traditional fishermen of Kharingcha baor at Chaugachha upazilla in Jashore, Bangladesh. The survey was conducted on 100 peoples from 70 families of the fishermen in the study area. It was found from the study that $94 \%$ fishermen were comprising of males, while $6 \%$ were of females. Among them, the majority was Hindus (88\%) and the minority was Muslims $(12 \%)$. During the survey, the proportion of semi paka houses were documented to be $88 \%$, while kancha were $12 \%$, and all the families had electricity facilities. It was found that $20 \%$ of fishermen had no education, $6 \%$ had passed SSC-HSC examinations, $14 \%$ had passed $6-10$ classes and $24 \%$ had passed $1-5$ classes. It revealed that $84 \%$ of fishermen were married and $16 \%$ were unmarried. Throughout the study, $33 \%$ of the fishermen were found to be dependent on village doctors, $40 \%$ on upazilla hospital and $27 \%$ on MBBS doctors. Several types of local boats and dingi nouka as well as nets such as tana jal (surrounding net), set bagnet, khapla jal (cast net), 
thela jal (push net) etc. were used for the harvesting of different fish species (Labeo rohita, Catla catla, Cyprinus carpio, Cirrhinus mrigala, Heteropneustes fossilis, Channa striatus, C. punctatus etc.). Averagely, $35-80 \mathrm{~kg}$ fish per day was caught by a group of fishermen using a boat. The majority of the fishers sold their harvested fishes upon the fulfillment of their demands. The monthly mean income of fishermen was around BDT. 5,000-15,000 in the baor area. Among the fishermen, $56 \%$ of them were observed to lend money from money lenders and $44 \%$ from the NGOs for their fishing-related activities and livelihoods. It revealed from the present findings that the traditional fishermen of Kharingcha baor require more technical, organizational and institutional helps for the improvement of their socio-economic condition and sustainable livelihood.

Keywords: Fishermen; livelihood; socio-economics; Kharingcha Baor; Chaugachha Upazila; Jashore.

\section{INTRODUCTION}

The fisheries sector is considered to be the most dynamic and productive sector, which have a great potential for the development of the agrobased economy in Bangladesh [1]. Fish and fishery resources play a vital role in improving socio-economic conditions of the fishermen and related peoples those are involved with its industries [2]. It also plays important combating mal-nourishment, earning foreign currency and creating employment opportunities in Bangladesh [1]. This country is blessed with huge water bodies in the form of rivers, canals, natural depressions (haors and beels), Kaptai lake, Ox-bow lakes, ponds, tanks, seasonally flooded areas and the Bay of Bengal. Bangladesh is endowed with very considerable areas of marine, estuarine and inland water bodies with a great potential of fisheries and aquaculture [3].

Being an agro-based riverine country, Bangladesh is situated in the subtropical regions covering an area of $1,47,570 \mathrm{~km}^{2}$. Bangladesh has been considered as one of the most suitable and productive inland fisheries regions in the world [1]. The inland water bodies are rich in freshwater fish species comprising 260 indigenous, 12 exotic and 24 freshwater prawn species [4].

Fish is a popular complement to rice in the national diet, giving rise to the adage MaacheBhate Bangali ("a Bengali is made of fish and rice") [5]. The fisheries can broadly be classified into three categories: inland aquaculture, inland capture and marine fisheries, of which the inland aquaculture sector is contributing more than $55 \%$ of the total production [6]. The fisheries sector plays a very important role in the national economy, contributing $3.69 \%$ to the GDP (gross domestic product) of the country and $22.60 \%$ to the agricultural GDP [7]. Over the last 10 years (2004-2005 to 2013-2014 FY), the fisheries growth was fairly steady at an average of $5.38 \%$ per year [8]. This sector experienced more or less consistent growth rate, ranging from $7.32 \%$ growth in $2009-2010$ to $4.04 \%$ growth in 20132014 [9]. More than 2\% of Bangladeshi export value comes from the inland fisheries sector. Given proper government support, the fisheries sector has ample potential in creating various types of ancillary industries in rural areas that often have a high rate of economic return. These employment opportunities for poor rural citizens would also stem their migration to urban areas. Fish supplements to about $60 \%$ of the daily protein intake by the peoples of Bangladeshi [6]. It has been reported that over 17 million peoples along with around 1.4 million women are depended on fisheries and aquaculture sectors for their livelihoods through fishing, farming, fish handling, and processing [10]. Different surveys revealed that more than $80 \%$ of laborers engaged in the fish processing industries were women [11].

In recent years, the bulk of the production has been obtained from marine $(16.78 \%)$ and freshwater $(83.22 \%)$ wild capture fisheries. In 2015-2016, Bangladesh was the $5^{\text {th }}$ in world aquaculture production, which accounted for half of the country's total fish production $(55.15 \%)$ [6]. In 2014-2015, total fishery production of Bangladesh was $3,684,245$ metric tons, of which $1,023,991$ metric tons was obtained from inland capture fisheries and 2,060,408 metric tons from inland aquaculture. There have been few reviews on the development and potential of fisheries and aquaculture in many parts of Bangladesh but no studies have been published on the present status of fisheries in the country.

Kharingcha baor is situated in Chaugachha upazilla, Jashore, Bangladesh. The shape and size of this baor is not so wide. However, it has a 
great impact on the economy of the surrounding villagers of Kharingcha, Madhobpur, Debaloy, Kamlapur etc. There were two phases in income earning activities of the peoples in Kharingcha baor. One of them was before 1960-61s, when the peoples were based on the cultivation of agricultural products and another was after 196061s, when peoples had changed their income earning activities to fishing. The villages of fishermen are typically situated in remote areas where there are no modern communication systems, having a very low impact on the developmental and socio-economic condition in the society. There have been no reasons to deny that the fishing communities are the most disadvantaged and poorest groups in Bangladesh [10] including the fishermen (herein referred to as the small-scale traditional fishermen) in the Kharingcha baor. Except fishing, they do not have any income earning opportunities to carry out their living expenses throughout the year and in idle periods, they do not have any alternative incomes sources. For these reasons, they have been facing serious problems towards the improvement of their livelihood and socio-economic conditions. For the overall planning and development, and implementation in fisheries sector, it is necessary to have the sound knowledge about the livelihood patterns of the related people. This study is therefore, focused specifically on the present condition of capture fishery and socioeconomic status of the small-scale traditional fishermen in and around Kharingcha baor. With this aim in view, a comprehensive field survey was conducted to investigate the socio-economic condition of the fishermen in Kharingcha baor and to find out some possible suggestions to uplift the livelihood status of local fishermen.

\section{MATERIALS AND METHODS}

\subsection{Study Area}

The study was conducted on the fishermen of Kharingcha baor, which is situated in Chaugachha upazilla under Jashore district, Bangladesh. Despite the size and shape of the baor is not so wide, it has a great impact on the economy of the surrounding villagers of Kharingcha, Madhobpur, Debaloy, Kamlapur etc. (Fig. 1 and Fig. 2). These areas were selected for conducting the survey on the socio-economic conditions of fishermen, which were chosen randomly.

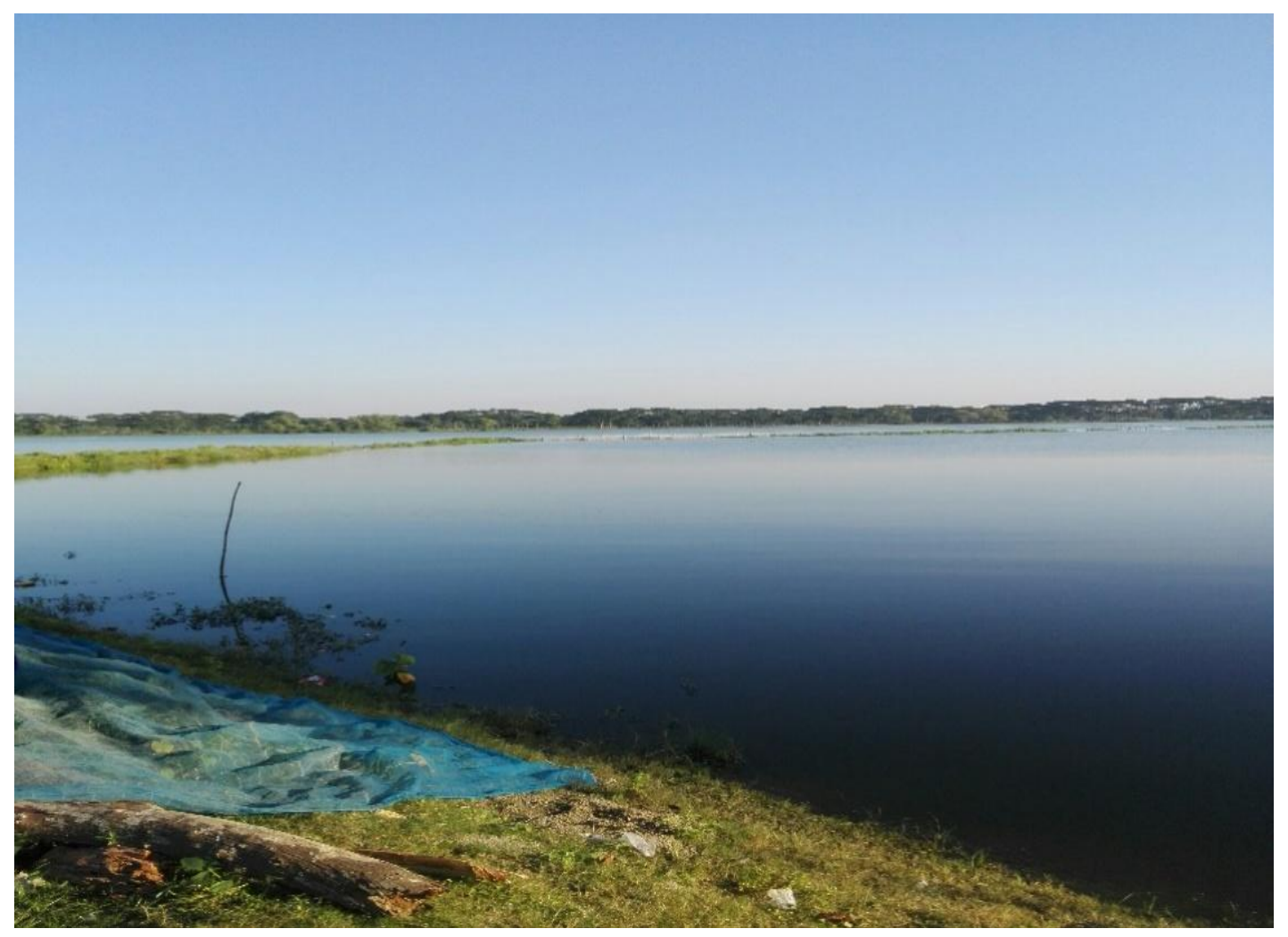

Fig. 1. A snap short of Kharingcha baor 


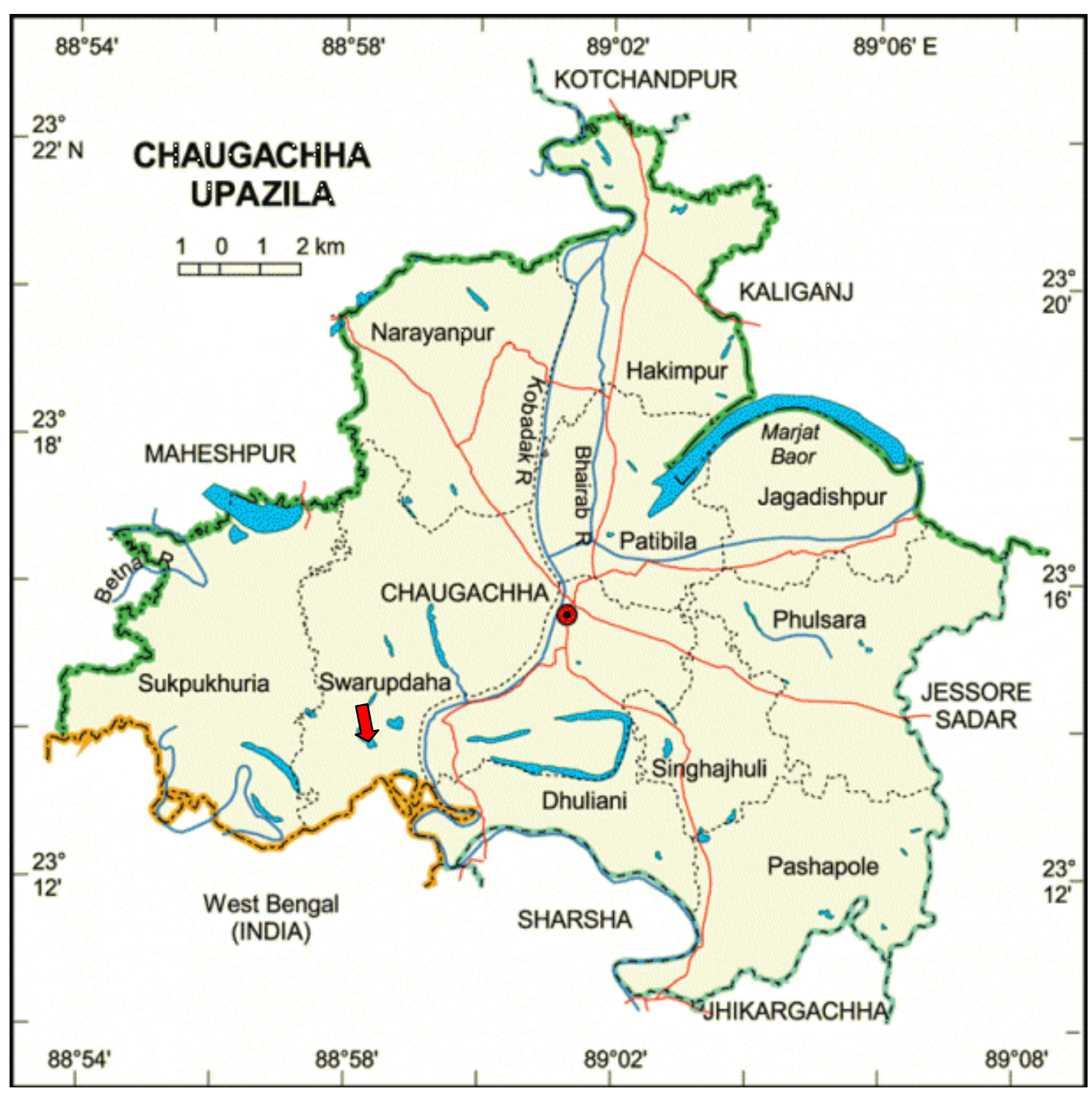

Fig. 2. Map of Chaugachha upazilla, showing the study area of Kharingcha baor in Jashore district, Bangladesh

\subsection{Field Survey and Data Collection}

For the collection of data on various aspects of socio-economic conditions of fishermen, field survey was conducted in the study areas of Kharingcha baor for a period of four months from September to December, 2020. Field visits (twice a month) were made during this time to collect necessary information. About 100 fishermen were randomly selected from the study areas. A range of participatory rural appraisal (PRA) and personal interview were applied with different degree of effectiveness. The collected data was then gathered, sorted and interpreted according to the objectives and parameters as well. Relevant information and literature were collected from both primary and secondary sources, which are as follows:

\subsubsection{Primary data}

A well-structured questionnaire was used to collect the primary data through field survey at the village level. Data were collected by both the physical observation and interview with fishermen who are involved in fishing activities.

\subsubsection{Secondary data}

Throughout the entire study, baor management activities and relevant information were collected through appropriate literature review and related publications from Upazilla Fisheries Office (UFO) and annual research reports. 


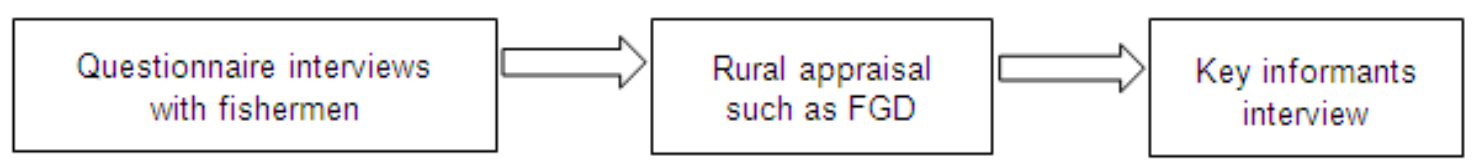

Data involving cost-benefit analysis were also done. Data related to socio-economic conditions viz., education status, age-group and sex ratio, occupation type, religious status and family size of the fishermen were collected during the survey.

In the present investigation, the widely used PRA tool viz., focus group discussion (FGD) was conducted with the fishermen in the community. During the study, FGD was utilized to obtain a general idea of particular issues such as exiting fish composition, fishing system and also the improvement of the production of Kharingcha baor as well as its biodiversity and socioeconomic conditions of the fishermen etc.

\subsection{Data Processing and Analysis}

The collected data was sorted, encoded, summarized and processed for analyses. These data were verified to eliminate all possible errors and inconsistencies. The analysis of collected data was mainly based on the tabular description technique.

\section{RESULTS}

The relevant data on the socio-economic characteristics viz., age group, sex, marital status, religion, family type, number of members in their family, educational status of the fishermen, use of electricity, yearly income and expenditure per month, the fishing gear and craft ownership, loan, dadon, etc. were collected throughout the study period and are described as follows:

\subsection{Age Group}

It was observed from the questionnaire interview that $6 \%$ peoples engaged in fishing activities were belonged to the age group below $18,20 \%$ were between 18 and $30,64 \%$ were between 30 and 45 , while the rest $10 \%$ peoples were above the age group of 45 (Fig. 3 ).

\subsection{Religion}

Selected areas in the Kharingcha baor were generally crowded with lower caste Hindu families and most of them were engaged themselves in fishing as a profession of their ancestries. Out of 100 fishermen, only 12 of them were found to be Muslims during the survey. So, the Muslim and Hindu fishermen were $12 \%$ and $88 \%$, respectively (Fig. 4).

\subsection{Marital Status}

The study was conducted to see the marital status of the fishermen. It revealed that the majority $(84 \%)$ of the fishermen were married and only $16 \%$ of the active fishermen were found to be unmarried (Fig. 5). No divorced and oppressed fishermen were observed in the survey area of Kharingcha baor.

\subsection{Fishermen Type}

From the study area, it was observed that $94 \%$ fishermen were male and only $6 \%$ were female (Fig. 6).

\subsection{Family Type}

Families in the rural Bangladesh are categorized into two major types such as: 1) Nuclear family, which is composed of the married couples with children and 2) Joint family, which is comprised of a group of peoples related by blood and/or by law. A nuclear family typically consists of the members of two generations (parents and children), while the joint family largely constructs with members from three or more generations as well. The present study showed that $47 \%$ families were nuclear, whereas $53 \%$ were joint families in the study area of Kharingcha baor (Fig. 7).

\subsection{Family Member's Age Group}

In the study area, a total of 400 members were found in the 100 fishermen families of which 200 were adult, 100 were children and 100 were old.

\subsection{Family Size}

The highest family size (46\%) was found in the 56 members family and the lowest $(20 \%)$ was obtained in the 7-8 members, while $34 \%$ peoples lived in the family, consisting of 3-4 members (Fig. 8). 


\subsection{Educational Status}

Out of 100 fishermen examined in the Kharingcha baor, $20 \%$ had no education, $6 \%$ had passed SSC-HSC, $14 \%$ had passed $6-10$ class and $24 \%$ had passed 1-5 class, while only literate who are able to reading and writing was $36 \%$ (Fig. 9).

\subsection{School Going and Dropout Children}

Total school going children in the study area of Kharingcha baor were found to be $57 \%$ boys and $43 \%$ girls. However, $63 \%$ girls and $37 \%$ boys were dropped-out from their studies after the primary education level.

\subsection{House type}

In the study area, houses of the fishing community were of two main types: 1) Kancha made of bamboo and talli or tin with mud flooring, 2) Semi-paka - made of wood or/and tin and floor is made of concrete. The study revealed that $88 \%$ of housing structures were semi-paka, $12 \%$ were semi-kancha and paka were not found (Fig. 10).

\subsection{Use of Electricity}

It was found in the survey area of Kharingcha baor that the facilities of electricity were comparatively well due to its position (near to the city area). The result indicated that 100\% fishermen had the facility of using electricity.

\subsection{Funding Sources}

The overall economic conditions of the villagers in the survey area was not so well. They usually incurred money for buying nets and small boats as well as their refurbishment and maintenance. Due to lack of necessary funds, the fishermen had needed to borrow money for investment in their fishing activities. Grameen bank, NGOs and local money lenders were the major sources of borrowing money by the fishermen in the study area. Almost all of the fishermen (64\%), who were involved in fishing, burrowed money from dadon, while $36 \%$ of them used their own money for buying nets and boats.

\subsection{Sources of Drinking Water}

The study showed that $80 \%$ people had own tube-well while $20 \%$ people did not have their own and therefore, they used neighbor's tubewell for drinking water and other domestic purposes (Fig. 11).

\subsection{Training on Fishing}

In the study area, fishermen were not received any training on improved fishing system.

\subsection{Fishing Gears and Boats}

Many fishermen did not possess their own net but carried out fishing by borrowing nets from others. Several nets such as tana jal (surrounding net), khapla jal (cast net), set bag nets and thela jal (push net) were used by the fishermen for catching of fishes like rui (Labeo rohita), catla (Catla catla), common carp (Cyprinus carpio), calibaus (Labeo calbasu) etc. in Kharingcha baor. Usually medium-sized boats were used for the harvesting of fishes. Some small-sized boats were also used. However, some fishermen had their own boats, some purchased boat through group-ownership and the rests were obtained from money lenders.

\subsection{Species Composition of the Catch}

Most fishermen reported that rui ( $L$. rohita) catch was dominated over other species such as catla (C. catla), common carp (C. carpio), calibaus ( $L$. calbasu) etc. Averagely $35-80 \mathrm{~kg}$ fishes per day were harvested by a group of fishermen in the investigated area of Kharingcha baor. In addition, they caught some small indigenous fishes such as shing (Heteropneustes fossilis), magur (Clarias batrachus), koi (Cyprinus rubrofuscus), punti (puntius sarana) etc.

\subsection{Market Price of Fishes}

Actual prices of the harvested fishes were high, but the fishermen obtained a less amount as compared to those in the market. On the other hand, the fishermen received loans at the high rates of interest for their foods, clothes, houses, daughter's marriage, medical treatment as well as making boats and fishing gears. During the lean fishing period, the fishermen were obliged to sell their fishes at a low price to return loan money to the lenders. According to their data, BDT. $180-200 / \mathrm{kg}$ for rui and catla, BDT. 30-40/kg for silver carp and BDT. 50-60/kg for tilapia were paid to them. 


\subsection{Health Facilities}

It was found during the study period that, around $33 \%$ of the fishermen were dependent on village doctors, $40 \%$ on upazilla hospital and $27 \%$ on MBBS doctors (Fig. 12).

\subsection{Association with Organizations}

From the survey, it was revealed that about $50 \%$ people were associated with Somitee, $32 \%$ with NGO and $18 \%$ with Grameen Bank (Fig. 13).

\subsection{Marketing System}

During the survey, $65 \%$ fishermen were found to sell their fishes to the dadonders/mohajons, $25 \%$ to the retailers and $10 \%$ to the consumers directly (Fig. 14).

\subsection{Annual Income}

During the interviews, BDT. 350 per day was found to be the highest income of the fishermen from selling their harvested fishes, while the lowest income was BDT. 300. Moreover, in every year, many people are getting involved in fishing as a seasonal or part-time occupation. As a result, fishing pressure has been continuously increased in the baor. The results obtained from the present study demonstrated that BDT. $50,000-70,000$, BDT. 71,000-1,00,000 and BDT. $>1,00,000$ were the annual incomes of $20 \%, 48 \%$ and $32 \%$ fishermen, respectively (Fig. 15).

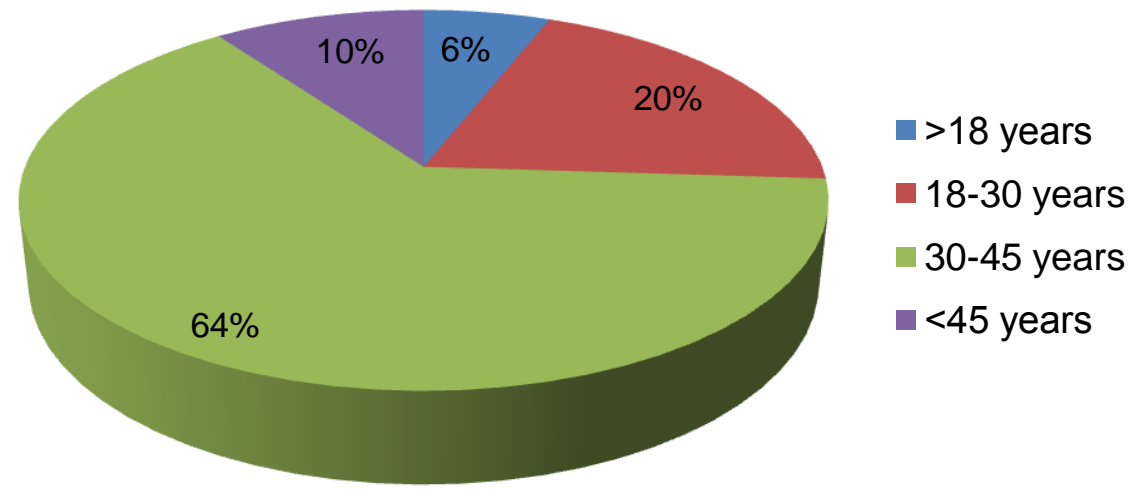

Fig. 3. Age group of the fishermen in the study area of Kharingcha baor

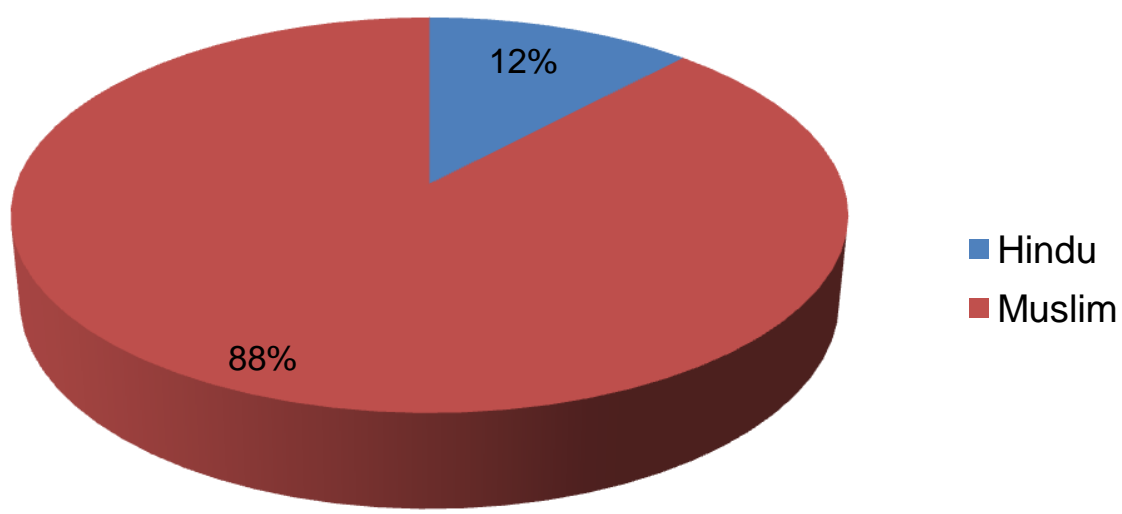

Fig. 4. Religion status of fishermen in the study area of Kharingcha baor 


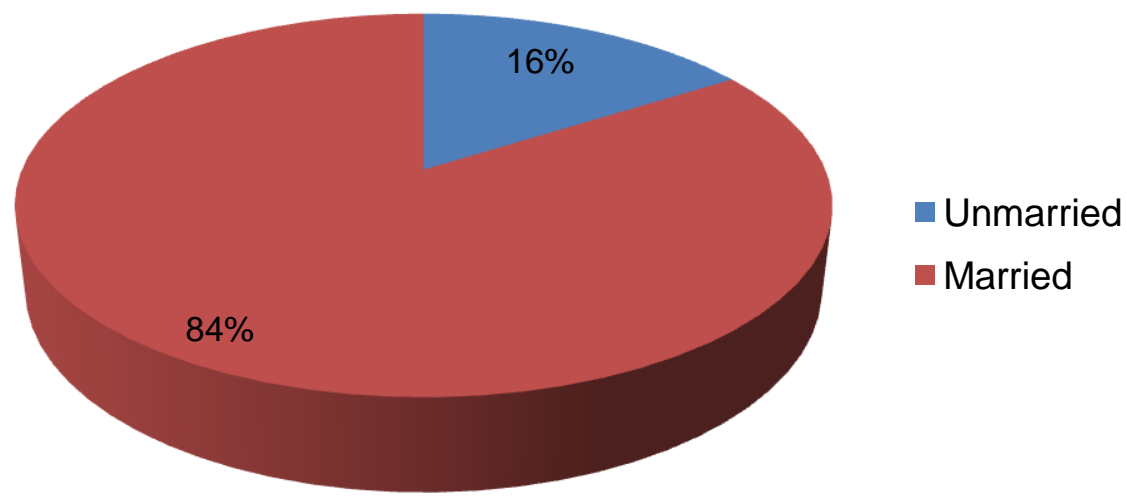

Fig. 5. Marital status of the fishermen in the study area of Kharingcha baor

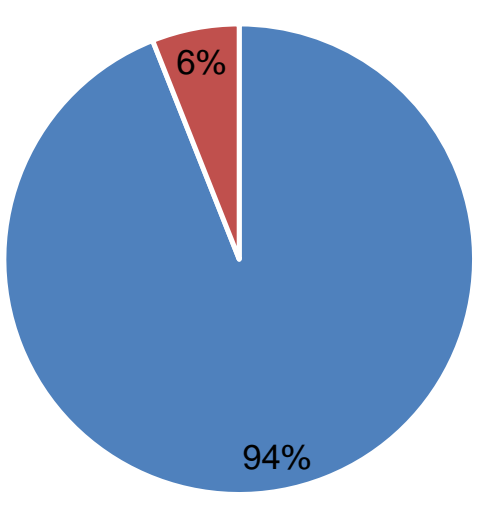

- Male fishermen

- Female fishermen

Fig. 6. Types of fishermen in the study area of Kharingcha baor

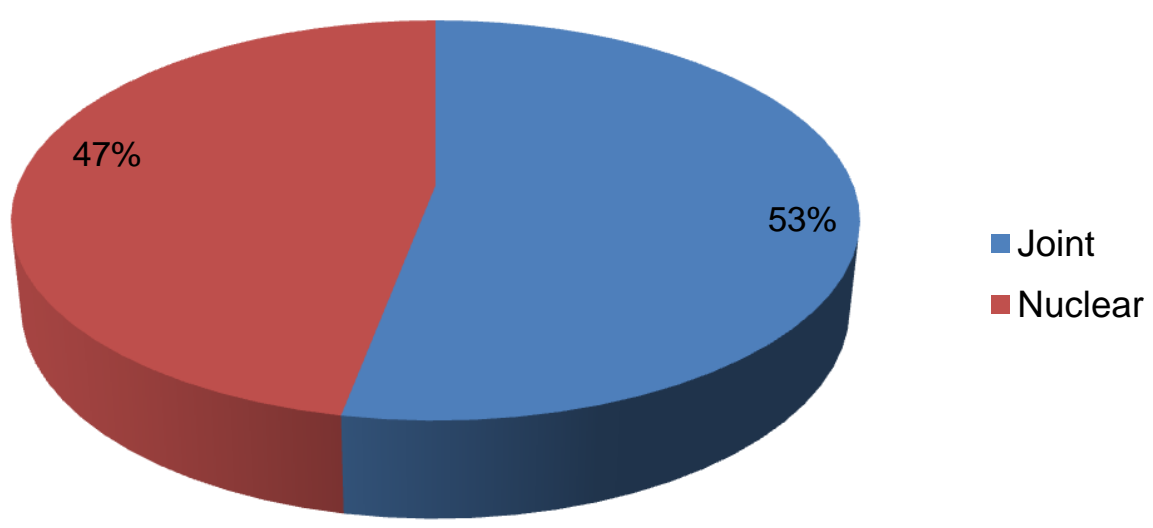

Fig. 7. Family types of the fishermen in the study area of Kharingcha baor 


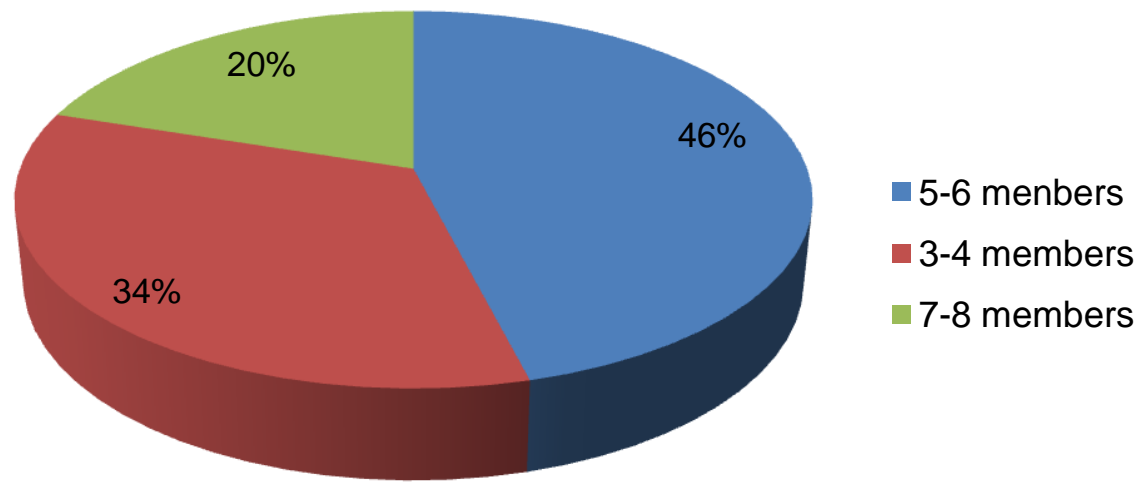

Fig. 8. Family size of the fishermen in the study area of Kharingcha baor

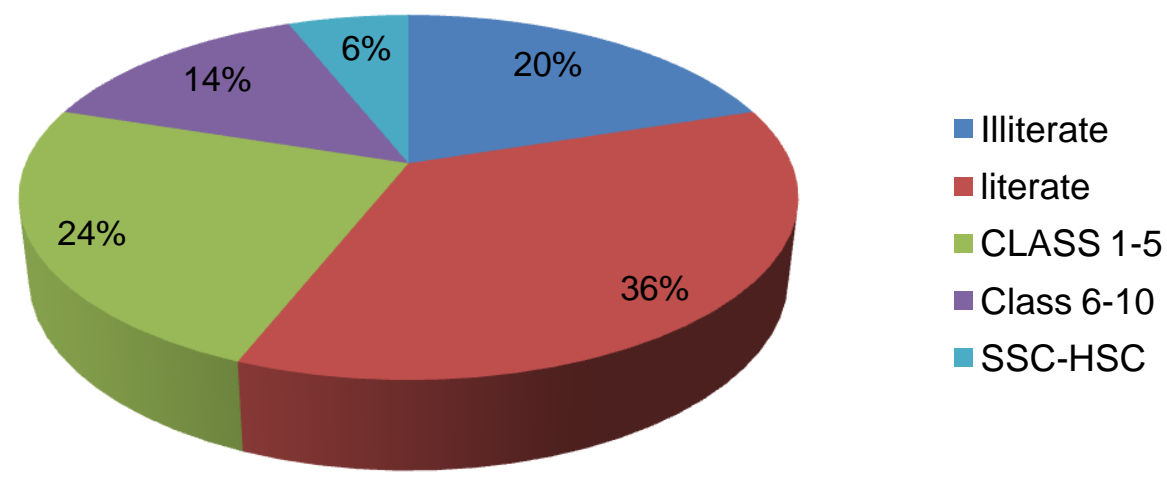

Fig. 9. Educational status of the fishermen in the study area of Kharingcha baor

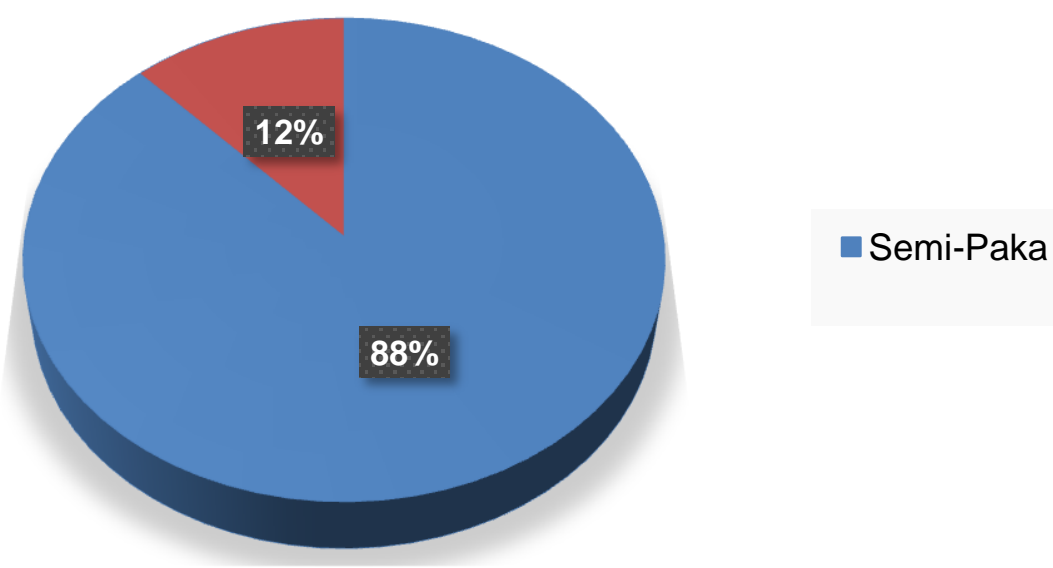

Fig. 10. House type of the fishermen in the study area of Kharingcha baor 


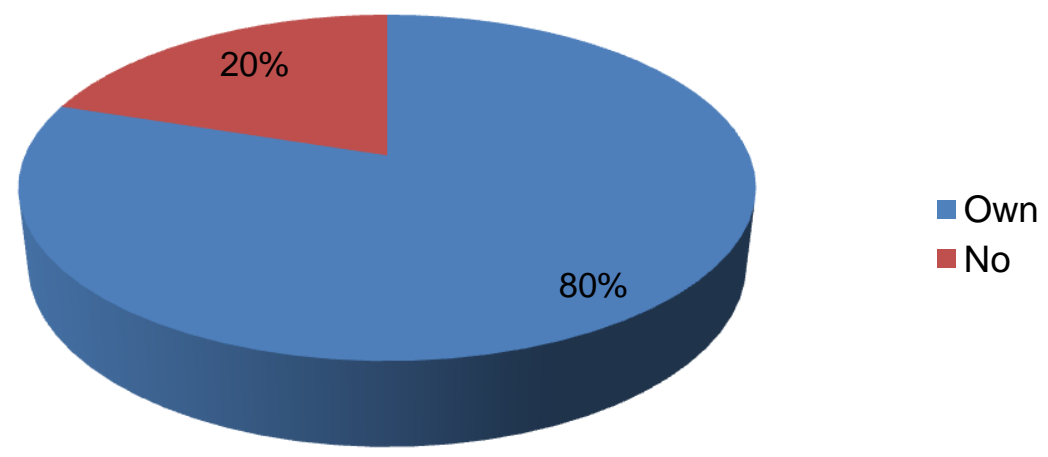

Fig. 11. Sources of drinking water of the fishermen in the study area of Kharingcha baor

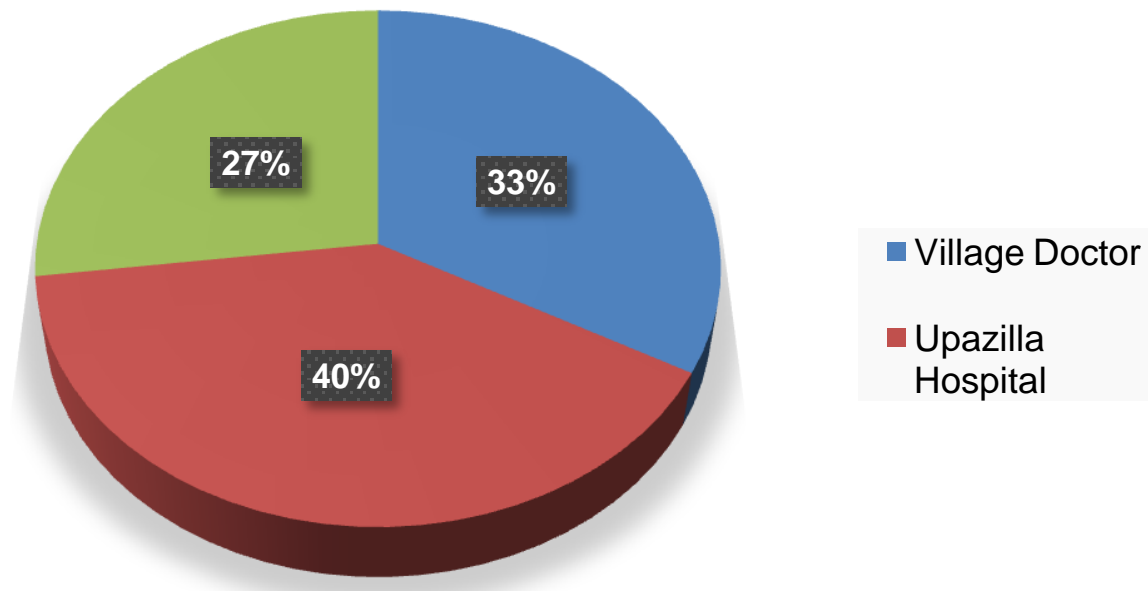

Fig. 12. Health facilities of the fishermen in the study area of Kharingcha baor

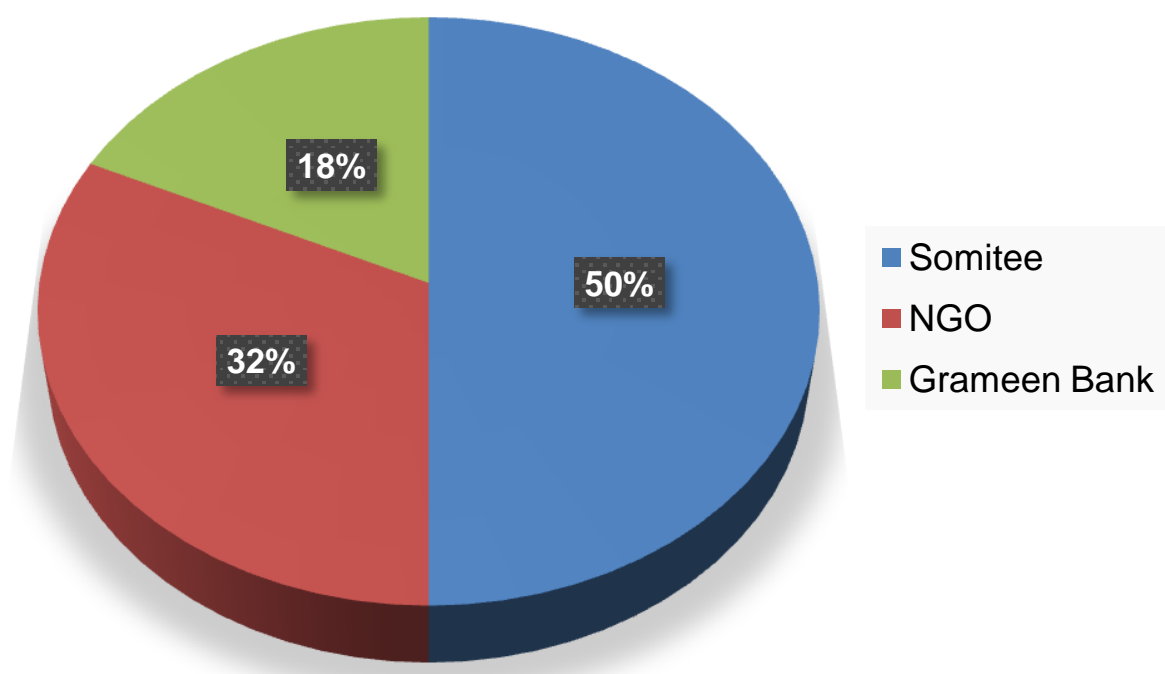

Fig. 13. Association with organizations of the fishermen in the study area of Kharingcha baor 


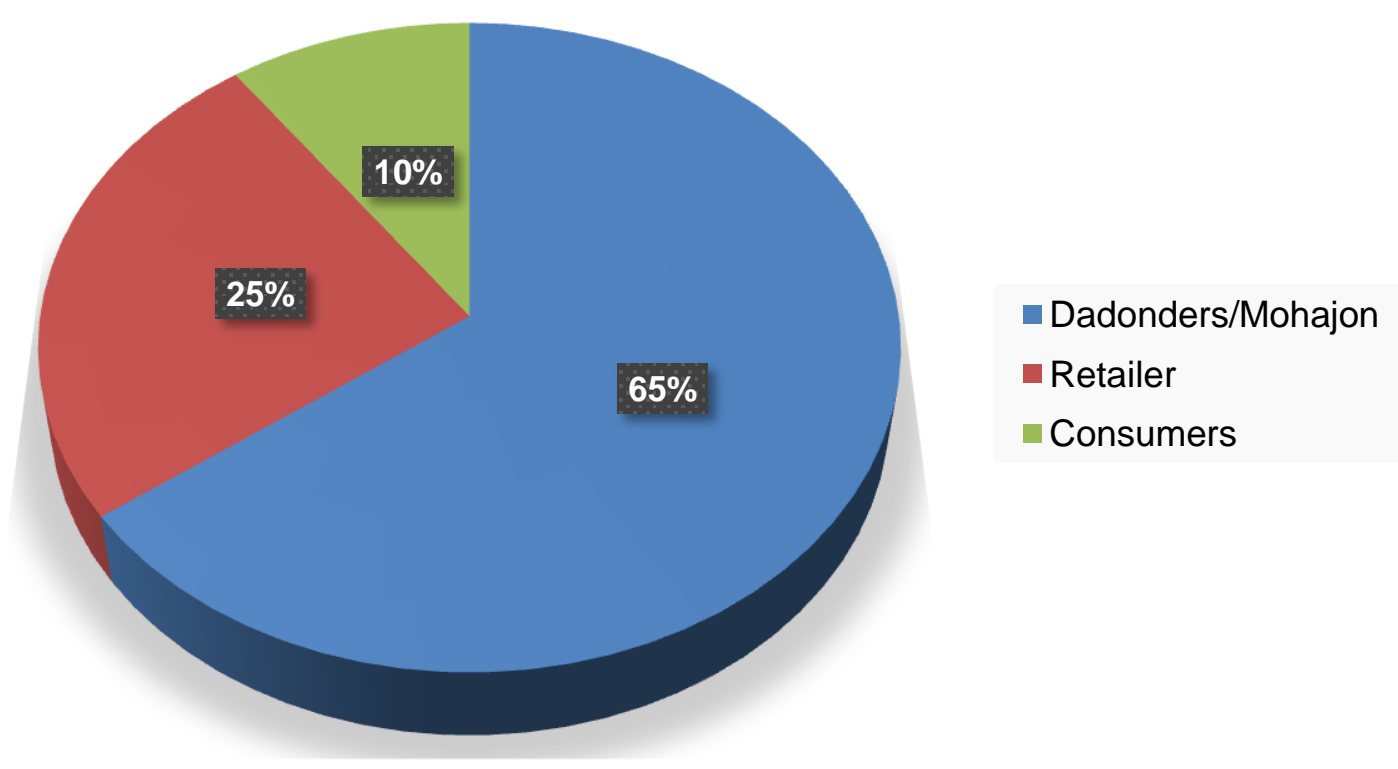

Fig. 14. Marketing System of the fishermen in the study area of Kharingcha baor

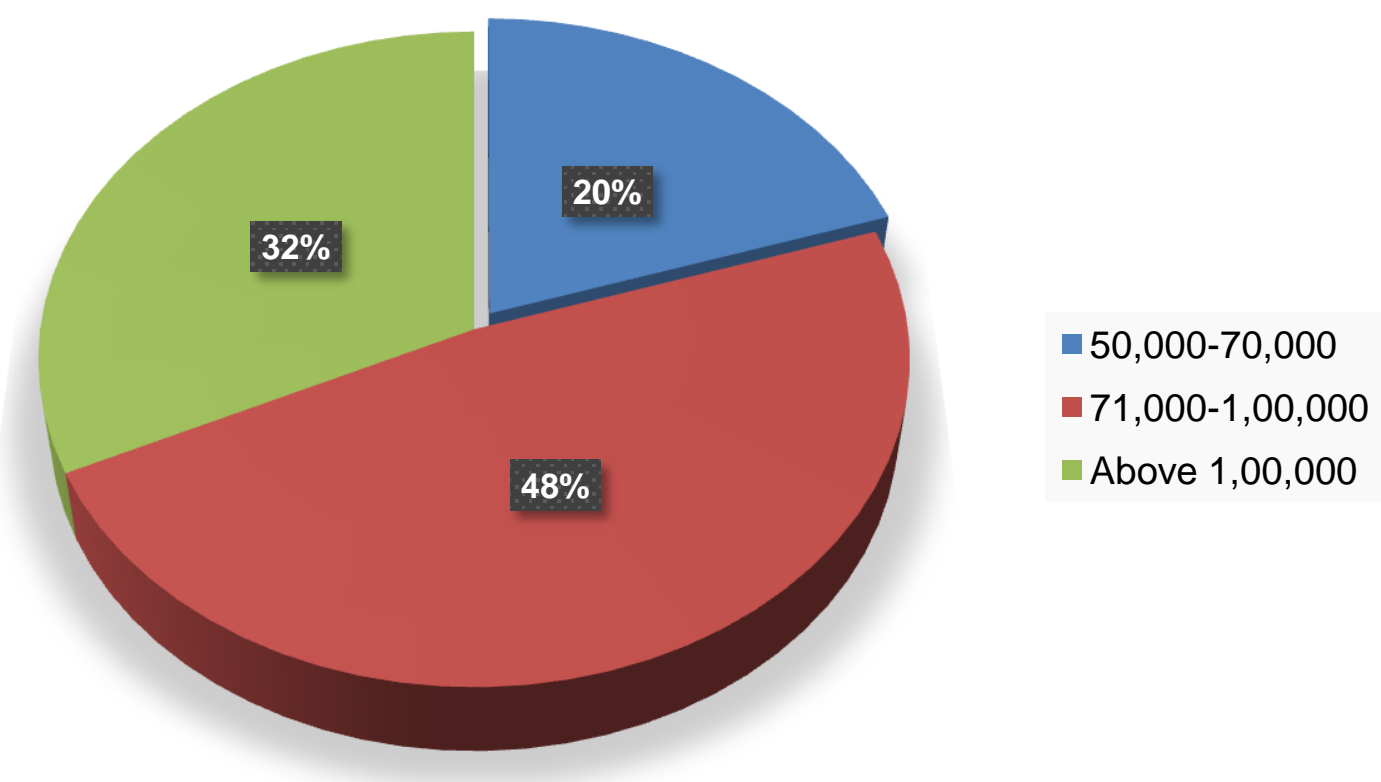

Fig. 15. Annual income of the fishermen in the study area of Kharingcha baor

\section{DISCUSSION}

It was observed from the present study that the highest numbers of the fishermen's age were 30 to 45 years $(64 \%)$ and the lowest $(6 \%)$ were under 18 , indicating that the middle age groups were involved in fishing activities around the Kharingcha baor area. Ahmed [12] in Tangail and
Ahmed [13] in coastal region had reported that $66 \%$ and $70 \%$ were under the 40 years of age, respectively. In our study area, the majority of the fishermen were Hindus (88\%) and minority of them were Muslims (12\%). The dominance of Hindus may be due to the fact that they understood as fishing is their ancestral profession. In the recent years, the Muslim 
peoples are also considered fishing as a profession of their livelihood due to the changing socio-economic structures, lack of employment opportunities and realizations of the fishing profession as a source of income. The study of Chantarasri [14] in the Sundarbans Reserve Forest stated that majority of the fishermen were Muslim (68\%), while Hindu fishermen (32\%) were the lowest [13]. This kind of dissimilarity may also be occurred due to the regional variations. During the present investigations, majority of the fishermen (84\%) in the baor area were found to be married, while only $16 \%$ of them were unmarried. Similar results were also reported by Ahmed [12] in Tangail, Mannu [15] in Kuakata and Shamima [16] in Gallamari, who found during their studies that the fishermen were dominated by married peoples of $94 \%, 92 \%$ and $70 \%$, respectively.

It was observed in the survey area that fishermen lived in joint and nuclear families were $53 \%$ and $47 \%$, respectively. Throughout the baor area, nuclear family was found to be popular over the joint family due to the fact that the fishermen were getting higher liberty in movements, greater economic opportunities, better cloths, better education and woman authority etc. The average family size 5-6 per family in the present study was larger than the national average of 4-5 people per house [17] in case of single family.

BBS [15] classified literate persons as those who can write a letter in any language. In the study area, there was $6 \%$ H.S.C and S.S.C passed fishermen and $24 \%$ had passed class V, whereas $36 \%$ fishermen could sign only and $20 \%$ were illiterate. Shahjahan [18] reported that $63.33 \%$ of riverine fishermen were illiterate, $31.67 \%$ had up to primary level of education, while only $5.00 \%$ of them had studied the secondary level in the research area of the Jamuna river. This might be due to the reasons that most of the fishermen in the river area were illiterate and they engaged their children in fishing rather than any educational activities. The results of the present study are in close agreement with the previous findings.

Shamima [16] reported that $20 \%$ fishermen used electricity in Gallamary fishing community, Khulna. Momotaz [19] reported that $90 \%$ fishermen had enjoyed electricity facility and 10\% fishermen did not get facilities to use electricity. Hossain [20] reported that around 95\% fishermen enjoyed electricity facility, while $5 \%$ of them did not have the opportunity to utilize electricity. All the fishermen in the study area of Kharingcha baor had the access to use electricity and none of them were deprived of using electricity in their daily life.

Fish as essential food moves towards the focal positions in the dwelling milk and meat resources of Bangladesh and the entire country defines himself by the proverb "Rice and fish, that's Bangalee" [3]. In the recent years, few changes have been occurred (i.e., traditional small boats are replaced by engine boats) in the lives of the fishermen of Bangladesh. Nevertheless, other man-made and environmental changes severely affect the fishermen and their livelihoods. Owing to the changing climatic conditions, cyclonic storms are occurring repeatedly and severely, degrading the coastal areas, demolishing the houses of the fishermen as well as destroying their boats and nets to a greater extent. The extremely severe cyclonic storm, for example SIDR, hit the coast of Bangladesh on 15 November, 2007, and left a trail of chaos. Thousands of individuals were killed and countless peoples lost their shelters and livelihoods in the affected coastal areas during that time.

Water pollution and overfishing cause havoc to the health and lives of the fishermen. Due to the shrinking population of larger fishes, CPU (catch per unit efforts) is decreasing in an alarming state and therefore, more and more fishing nets and gears remain empty every day. In order to survive, the fishermen must have to go for the catching of small and young fishes, aggregating to the shallow coastal areas and hence, causing the severe destruction of fish population and biomass as well.

Over the resent centuries, the fishermen have been contributing a lot to our national economy. Therefore, in regards of our country's economic development, improvement of their livelihoods and socio-economic conditions are deemed very important, and for this standpoint, development and management of capture fisheries must be done in a very appropriate, significant and sustainable manner.

During the interview by asking the pertinent questions to the fishermen, the following problems were identified in the study area of the Kharingcha baor:

- Lack of taking initiatives by the fishermen 
- Shortage of appropriate understanding, knowledge and consciousness amongst the fishermen

- Lack of unity and leadership, predominantly in challenging situations

- Week social cohesion

- Low income

- Lack of control over the fish market by the fishing community

- $\quad$ Due to money lending through Dadon from Mahajan, the fishermen could not get the actual price of their harvested fishes.

\section{CONCLUSION}

The findings obtained form the present study revealed that the overall livelihood patterns and socio-economic situations of the small-scale traditional fishermen in Kharingcha baor were not satisfactory. The fishermen were deprived of many amenities. Both fish production and fish fauna of the area were being drastically reduced due to environmental and manmade activities such as over-fishing, indiscriminate use of restricted fishing gears and as a whole, due to the lack of proper management strategy. Under these adverse situations of declining fisheries resources in Kharingcha baor, supplementary income from other than fishery is of great importance. Goat and sheep rearing, cow rearing, home-based vegetables cultivating, agro-farming, small-scale business etc. have been recognized as the significant alternate income earning sources for the male fishermen while, handcrafts manufacturing, nets making, and poultry and duck raising are specifically chosen for the women as well. Therefore, appropriate steps should need to be undertaken by the Government Organizations (GOs) and Non-Government Organization (NGOs) to assist the fishermen towards the adoption of these alternate income-generation activities.

To overcome the existing problems, the belowmentioned recommendations should need to be considered for implementation:

$\checkmark$ Founding a fisheries management component [a joint venture between Bangladesh Fisheries Development Corporation (BFDC) and Bangladesh Fisheries Research Institute (BFRI)].

$\checkmark$ Arrangement of loan facilities from the national, commercial and rural banks in cooperation with the extension services from the Department of Fisheries (DoF) might be an alternative solution to reduce the high rate of interest and proper trainings should be provided to the fishermen by GO and NGOs.

$\checkmark$ Fisheries research organizations, management authorities, local administrations and law enforcement departments must be united to plan, formulate and integrate appropriate policies and strategies to manage successfully the national resources through the harvesting and maintaining of maximum sustainable yield (MSY).

$\checkmark$ The livelihoods of fishermen can be improved through controlling/banning dadon and providing easy bank loan. It is the matter of hope that now fishermen are getting ID card and the Government has decided to give incentives to the fishermen for the banned seasons as they cannot go for fishing during these times.

\section{DISCLAIMER}

The products used for this research are commonly and predominantly used products in our area of research and country. There is absolutely no conflict of interest between the authors and producers of the products because we do not intend to use these products as an avenue for any litigation but for the advancement of knowledge. Also, the research was not funded by the producing company rather it was funded by personal efforts of the authors.

\section{ETHICAL APPROVAL}

As per international standard, written ethical permission has been collected and preserved by the author(s).

\section{COMPETING INTERESTS}

Authors have declared that no competing interests exist.

\section{REFERENCES}

1. Shamsuzzaman MM, Mozumder $\mathrm{MMH}$, Mitu MJ, Ahamad AF. Fisheries resources of Bangladesh: Present status and future direction. Aquac Fish. 2020;2(4):145-156.

2. Shamsuzzaman MM, Xiangmin X, Islam MM. Legal status of Bangladesh fisheries: Issues and responses. Indian J Geo-Mar Sci. 2016;45(11):1474-1480.

3. Rahman AKA. The small-scale marine fisheries of Bangladesh. In: socioeconomic issues in coastal fisheries 
management. Proceeding of the IPFC symposium, Bangkok, Thailand. FAQ IndoPacific Fisheries Commission (IPFC). 1994;8:170-175.

4. DoF. Fisheries Statistical Yearbook of Bangladesh 2007-08. Fisheries Resources Survey System, Department of Fisheries (DoF), Ministry of Fisheries and Livestock, Government of the People's Republic of Bangladesh, Dhaka, Bangladesh; 2009.

5. Ghose B. Fisheries and aquaculture in Bangladesh: Challenges and opportunities. Ann Aquac Res. 2014;1(1):1-5.

6. DoF. National fish week, compendium (in Bengali). Department of Fisheries (DoF), Ministry of Fisheries and Livestock, Government of Bangladesh, Dhaka, Bangladesh; 2016.

7. FRSS. Fisheries statistical report of Bangladesh. Fisheries Resources Survey System (FRSS), Department of Fisheries, Bangladesh. 2016;32:1e57.

8. FRSS. Fisheries statistical report of Bangladesh. Fisheries Resources Survey System (FRSS), Department of Fisheries, Bangladesh. 2015;31:1e57.

9. Bangladesh economic review. Economic Advisers Wing, Finance Division, Ministry of Finance, Dhaka, Bangladesh; 2014.

10. BFTI. Bangladesh foreign trade institute, study on sector based need assessment of business promotion council- fisheries products. Kawran Bazar, Dhaka; 2016

11. DoF. National Fish Week Compendium (In Bengali). Department of Fisheries (DoF), Ministry of Fisheries and Livestock, Government of Bangladesh, Dhaka; 2015.

12. Ahamed NU. Report of the fishermen's socio-economic survey. Fisheries Survey and Monitoring Program, Department of Fisheries, Tangail. 1996;1-4.
13. Ahmed NU. A study on socio-economic aspect of coastal fishermen in Bangladesh. MS Thesis, Department of Aquaculture. Bangladesh Agricultural University, Mymensingh, Bangladesh; 1999.

14. Chantarasri S. Integrated resources development of the Sundarbans reserved forest. The draft reports on Fisheries Resources Management for the Sundarbans Reserved Forest, Khulna, Bangladesh (BGD/84/OSG) FAO- UNDP. 1998;5-171.

15. Mannu MU. Jeleder sukhdukh. The Daily Janakayrtha; 1999.

16. Shamima SH. Socio-economic condition of fishing community: Gallamary fish market, Khulna. BSc Thesis. Fisheries and Marine Resource Technology Discipline, Khulna University, Khulna, Bangladesh; 2000.

17. BBS. Statistical yearbook of Bangladesh, Bangladesh Bureau of Statistics, Statistical Division, Government of the Peoples Republic of Bangladesh, Dhaka. 2011; 580.

18. Shahjahan M, Miah MI, Haque MM. Present status of fisheries in the Jamuna river. Pakistan J Biol Sci. 2001;4(9):11731176.

19. Momotaz S. Socio-economic condition of small indigenous species beneficiaries at three villages (Garakhola, Chatiani and Jamira) of Phultala, Khulna. BSc Thesis. Fisheries and Marine Resource Technology Discipline, Khulna University, Khulna, Bangladesh; 2009.

20. Hossain MA. Socio-economic condition of fish farmers in Jessore District, Khulna. BSc Thesis. Fisheries and Marine Resource Technology Discipline, Khulna University, Khulna, Bangladesh; 2009.

(c) 2021 Uddin et al.; This is an Open Access article distributed under the terms of the Creative Commons Attribution License (http://creativecommons.org/licenses/by/4.0), which permits unrestricted use, distribution, and reproduction in any medium, provided the original work is properly cited. http://www.sdiarticle4.com/review-history/68743 